\title{
Mystery, Magic and Morals: Looking at themes and ideas in select Indian and Arabic Literature
}

\section{Aflah Zahoor}

\begin{abstract}
Arabic and Indian literature and culture are known for their richness and can be traced back to ancient times. Yet these texts written long back, from being passed down orally to becoming bestselling books hold relevance in our lives today. Fairy tales, fables, stories have a major impact on the cognitive development of children and form the major component of children's literature. Even adults find these stories, now even presented to us as series or movies fascinating. Indian and Arabic literature are rich in lingual and intellectual aspects, this paper looks at certain texts and tries to determine how they represent culture and ideology, reminding of cultural commonalities.
\end{abstract}

Keywords-Arabian nights, Fantasy, Islam, Literature, Panchatantra.

\section{INTRODUCTION}

A direct quotation, often attributed to Einstein, runs: "If you want your children to be intelligent, read them fairy tales. If you want them to be more intelligent, read them more fairy tales." Indian and Arabic folk literature has mostly been read in isolation rather than as something where one influences the other. Folk tales, orally passed from one generation to another convey a moral and intellectual effect to the readers and listeners alike. This paper aims to look at the similarities and differences between the folk literature of India as well as the Arabic tales. Focusing on some selected texts we will try to see how these are stories we have all grown up listening to but never tried to critically look at and understand what commonalities they have. This paper will attempt to look at the origin of these folk tales and the purpose they serve, placing the Arab and Indian texts parallel to one another. It will also throw light on the social and cultural background of the places in question. We will examine how successful these texts have been in the representation of the culture and society.

\section{SPREAD OF ARABIC LITERATURE IN INDIA}

From the very beginning Islam created waves across the world, further India was also under the rule of muslims. However, India was not part of the caliphate here as such but Turks and Mughals established sovereign powers in very less time and Delhi became the centre of their power. Arabic culture began developing in India which lead to wide access to Arabic language and literature. Madrassas started operating somewhere around this point with the main purpose of inculcating the knowledge of Arabic for religious reasons but later acquired an important status in the entire system of education. These madrassas produced major scholars in the field of Islamic religion and experts of language and literature. Also, Arabic as a language in india is important for the strengthening of the relationship between the two countries. Teaching of Arabic is focused on in india for this very reason. Students having attained proper knowledge of the language futher are allotted good jobs in the middle east and other Arabic speaking places. Knowledge of the language also strengthens the cultural bonds with certain communities, so to say.

"The rapid spread of the Islamic faith brought the original literary tradition of the Arabian Peninsula into contact with many other cultural traditions-Byzantine, Persian, Indian, Amazigh (Berber), and Andalusian, to name just a fewtransforming and being transformed by all of them. At the turn of the 21st century, the powerful influence of the West tended to give such contacts a more one-sided directionality, but Arab litterateurs were constantly striving to find ways of combining the generic models and critical approaches of the 
West with more indigenous sources of inspiration drawn from their own literary heritage."1

\section{WRITINGS IN INDIA}

Writings from South Asia, particularly the indian subcontinent is known for the rich and diverse languages, including Sanskrit, Prakrit, Pali, Bengali, Bihari, Gujarati, Hindi, Kannada, Kashmiri, Malayalam, Oriya, Punjabi, Rajasthani, Tamil, Telugu, Urdu, and Sindhi, among others, as well as in English. The term Indian literature is used here to refer to literature produced across the Indian subcontinent prior to the creation of the Republic of India in 1947 and within the Republic of India after 1947.

Literaturein India which set a benchmark in Indian writings mainly consisted of Hindu sacred writings, known as the Vedas, which wereoriginallywritten in Sanskrit. To the Vedas were added referential texts in the prose form such as the Brahmanas and the Upanishads. The production of Sanskrit literature extended from about 1500 BCE to about $1000 \mathrm{CE}$ and reached its height of development in the 1st to 7th centuries CE. In addition to sacred and philosophical writings, such genres as erotic and devotional lyrics, court poetry, plays, and narrative folktales emerged.

India's multiple languages have enriched it in many ways and this gift has acted as a boon to the literary production in the country, with varying cultures and ways of life ideas that are totally unique emerging from different parts of the country, making India a country rich and varied in literature. Fantasy literature has not been much of a focus in recent times but older fables and tales continue to have a major place in the genre. Children grow up reading Aesop's fables, Harry Potter and the like while in India we keep going back to Panchatantra and Vikramaditya's tales of wisdom which have set a benchmark in the genre of fantasy in India.

\section{THE ONE THOUSAND AND ONE NIGHTS}

"The One Thousand and One Nights (Arabian Nights) is easily the best known of all Arabic literature and which still shapes many of the ideas non-Arabs have about Arabic culture. The stories of Aladdin and Ali Baba, usually regarded as part of the Tales from One Thousand and One Nights, were not actually part of the Tales. They were first

\footnotetext{
${ }^{1}$ Roger Allen, http://www.britannica.com/EBchecked/topic/31722/Arabicliterature
}

included in French translation of the Tales by Antoine Galland who heard them being told by a traditional Arab storyteller and only existed in incomplete Arabic manuscripts before that. The other great character from Arabic literature, Sinbad, is from the Tales.The Thousand and One Nights is usually placed in the genre of Arabic epic literature along with several other works. They are usually, like the Tales, collections of short stories or episodes strung together into a long tale. The extant versions were mostly written down relatively late on, after the 14th century, although many were undoubtedly collected earlier and many of the original stories are probably pre-Islamic. Types of stories in these collections include animal fables, proverbs, stories of jihad or propagation of the faith, humorous tales, moral tales, tales about the wily con-man Ali Zaybaq and tales about the prankster Juha.The epic took form in the 10th century and reached its final form by the 14th century; the number and type of tales have varied from one manuscript to another.All Arabian fantasy tales were often called "Arabian Nights" when translated into English, regardless of whether they appeared in The Book of One Thousand and One Nights, in any version, and a number of tales are known in Europe as "Arabian Nights" despite existing in no Arabic manuscript."2

The art of creativity which is dominant in the story telling of the One Thousand and One Nights has time and again tickled the thoughts of many. It is perhaps the greatest gift of Arabic literature to the whole world, in all its forms, genres and themes. It has influenced other forms of art, literature, music, cinema etc and does so even now. The stories the Queen narrates to the king are full of twists and turns and have found place in various adaptations. Almost everyone is aware of the stories of Ali Baba, Alladin, Sindbad etc. These stories become a beautiful part of almost everyone's childhood. These tales later fascinated the west

"The first complete translation was done by Antoine Galland into French in the early 18th century, later, many European translations would follow in various languages, including English, French, German, and practically every other language, the most well-known being Sir Richard Burton's 16 volume, "The Thousand Nights and a Night" in 18851888. This epic has been influential in the West since Galland's translations. Many imitations were written, especially in France. Various characters from this epic have themselves become cultural icons in Western culture, such as Aladdin, Sindbad and Ali Baba. Part of its popularity may

${ }^{2}$ Arabic epic literature, World Heritage Encyclopedia 
have sprung from the increasing historical and geographical knowledge, so that places of which little was known and so marvels were plausible had to be set further "long ago" or farther "far away"; this is a process that continues, and finally culminate in the fantasy world having little connection, if any, to actual times and places. A number of elements from Arabian mythology and Persian mythology are now common in modern fantasy, such as genies, bahamuts, magic carpets, magic lamps, etc. When L. Frank Baum proposed writing a modern fairy tale that banished stereotypical elements, he included the genie as well as the dwarf and the fairy as stereotypes to go."Arab epic literature consisted of more than just Arabian nights. A german scholar discovered Arabic scripts and short stories in 1933 in the mosque ofHagia Sophia and translated it to german, a decade or two later the Arabic version was printed.

As Edward Said says in his Orientalism that the inroads of Orientalism made it difficult for even those with a genuine interest in the East to see it truthfully, so we don't really know if the European translators moulded the Arabic texts into something they desired, as they continue treating people for the Orient as the other, using varied spellings and words for Arabic terms that cannot be translated. Here, the west gets a chance of presenting the orient as exotic and change it 'according to it's own lens which can be dangerous. Although we see in many stories that female characters are presented to us as bold and independent, which is different from the general notion that women in Islamic environments are governed by patriarchy and the like. Inspite of that, many translations have objectified women. These translations involved a whole new population in the reading of these texts and started influencing new European texts as well.

Dante Alighieri's Divine Comedy, considered the greatest epic of Italian literature, derived many features of and episodes about the hereafter directly or indirectly from Arabic works on Islamic eschatology: the Hadith and the Kitab al-Miraj (translated into Latin in 1264 or shortly before as Liber Scale Machometi, "The Book of Muhammad's Ladder") $)^{3}$ concerning Muhammad's ascension to Heaven, and the spiritual writings of IbnArabi.

It all started in 9th century Baghdad during the Islamic golden age, under the ruling of the caliph Harun Al-Rashid, the region was ripe with scientific, cultural and religious

\footnotetext{
${ }^{3}$ Dante Alighieri, Liber Scale Machometi, "The Book of Muhammad's Ladder") concerning Muhammad's ascension to Heaven
}

prosperity. Art and music also flourished significantly during his reign. It was even said that the dome of his palace in Baghdad was capped with a bronze horseman, whose lance pointed in the direction from which enemy invasion might be expected. From this period was the beginnings of what we know of as the Arabian Nights today. Yes The Arabian Nights are that old if not older, as some sources believed that the Arabian Nights derived from the Jataka tales which were brought to the middle east by Indian traders. Meanwhile as all this was going on Western Europe was going through its dark ages period until the Italian Renaissance in the 14th century.

The Arabian Nights also introduced a lot of the techniques of fantasy writing that we see today in great literature, things like the embedded narratives and dramatic visualization. The Arabian nights is also was the first to utilize plot devices like Fate and Destiny and foreshadowing, again an Islamic understanding of things was represented here. What is also really fascinating is that the Arabian Nights also contains several elements that we see in fiction today like fantasy, horror, crime story, satire and believe it or not even Science fiction all have their place in the Arabian nights.

One of the best examples of this is The City of Brass. The Story features a group of travelers on an archaeological expedition across the Sahara to find an ancient lost city and attempt to recover a brass vessel that Solomon once used to trap a djinn. Along the way the group encountered a mummified queen, petrified inhabitants, life like humanoid robots and automata, seductive marionettes dancing without strings, and a brass horseman robot who directs the party towards the ancient city, which has now become a ghost town. Another good example is The Ebony Horse which features a flying mechanical horse controlled using keys that could fly into outer space and towards the Sun. The Arabian Nights is filled to the brim with stories like this.When you think about it all these great elements and more were mined like gold by other truly great fantasy authors to hone their craft after reading the Arabian Nights to create other great works of fiction. ${ }^{4}$

Whichever way you look at it, the contributions that the Arabian Nights and Arab folklore in general gave to the fantasy genre as a whole is that important, it really is, and we must not forget that. Every time you go through Arabian nights, you will be transported to a magical realm that is like

${ }^{4}$ http://www.isfdb.org/wiki/index.php/Series:Arabian_Nights 
no other and at the same time you are reliving some of the great history that the fantasy genre has to offer.

"They are central and elemental, still," says Paulo LemosHorta, an assistant professor of literature at New York University Abu Dhabi, who teaches One Thousand and One Nights,. "So yes, we stereotype and call it fantastical. But there was something revolutionary about these stories of merchants or cobblers - everyday people - which remind us that our histories are intertwined and interwoven."

\section{INDIAN WRITINGS, PANCHATANTRA}

The folklores and folktales have been an eternal part of every culture since ages. When it comes to Indian folk tales, the country of diverse religions, languages and cultures has a complete range of tales and short stories. Indian folklore has a wide range of stories and mythological legends, which emerge from all walks of life. The interesting stories range from the remarkable 'Panchatantra' to 'Hitopadesha', from 'Jataka tales' to 'Akbar-Birbal'. Not only this, the great Indian epics like 'Ramayana', 'Mahabharata' and 'Bhagvad Gita' are full of didactic stories inspired from the lives of great souls. Being full of moralistic values, Indian folklore makes perfect stories for children, who are required to be, instilled with right values. All these ancient stories have been passed from generation to generation, creating bondage of traditional values with present-day generation. The Panchatantra is an ancient Indian collection of interrelated animal fables in verse and prose. The original Sanskrit work, which some scholars believe was composed around the 3rd century BCE, is attributed to Vishnu Sharma.

Vetala Panchavimshati (Sanskrit: वेतालपज्चविंशति, IAST: vetālapañcaviṃśati) or Baital Pachisi ("Twenty-five (tales) of Baital"), is a collection of tales and legends within a frame story, from India. It was originally written in Sanskrit. The Vetala stories are popular in India and have been translated into many Indian vernaculars.Several English translations exist, based on Sanskrit renditions and on Hindi, Tamil, Bengali and Marathi versions. Probably best-known English version is that of Sir Richard Francis Burton which is, however, not a translation but a very free adaptation.

Literature and culture are deeply interrelated and both havea strong influence on one another, because during years and from the oldest of time, literature embodied culture and continues to directly influence it. Literature stands as a voice that expresses values and beliefs, and shows how people live as individual or as a group with this perspective and how their cultural life was and howtheir culture and traditions used to be. Literature becomes theideal tool to show the learners the certain culture. It gives a great opportunity for the learners to increase their world knowledge as they will haveaccess to a variety of contexts and, which is undoubtedly related tothe target culture. An identity intersection (Foss, 2002) is a graphic representation of interrelated and interconnected aspects of one person's cultural identity The intersection identifies the cultural groups that a person claims affiliation with and indicates how those cultural groups interact to influence the way that person lives their life. Therefore, we get back to the understanding that literature reflects culture and cultural interactions.

Now looking at the above mentioned categorical specifications associated to certain literatures, which here are Arabic and Indian fantasy writings we can ponder on the fact that what purpose do these texts serve? Fantasy is for sure everyone finds to be a pleasing read. Besides that these texts teach us about cultures, religious traditions, Arabic and Sanskrit terminology, life values, wisdom of ancient people, etc. In recent times works like Aliens In Delhi by Sami Ahmad Khan and The Simoqin Prophecies by Samit Basu have gained ample popularity in India, while books like The wrath and the dawn by Renee Ahideh is a popular contemporary Arabic fantasy novel.

Would Vikramaditya be known for his wisdom and Scheherazade be so famous for hercreative and imaginative tales that saved her from being executed? These stories are the representations of writers' imaginations, of how in those times they could fathom and create stories that have no parallels even now. We see that the Arabic and Indian writings in the genre of fantasy also play a major role in speaking about the prevalent conditions in the society at those times.

\section{CONCLUSION}

Looking at The thousand and one nights we come across an apt summarization in The Islamic Context of The Thousand and One Nights by Muhsin J. al-Musawi "Written by a number of authors over a stretch of centuries, The Thousand and One Nights depicts a burgeoning, urban Islamic culture in all its variety and complexity. As al-Musawi demonstrates, the tales document their own places and periods of production, reflecting the Islamic individual's growing exposure to a number of entertainments and temptations and 
their conflict with the obligations of faith. Aimed at a diverse audience, these stories follow a narrative arc that begins with corruption and ends with redemption, conforming to a paradigm that concurs with the sociological and religious concerns of Islam and the Islamic state. By emphasizing Islam in his analysis of these entertaining and instructional tales, al-Musawi not only illuminates the work's consistent equation between art and life, but he also sheds light on its underlying narrative power. His study offers a brilliant portrait of medieval Islam as well, especially its social, political, and economic institutions and its unique practices of storytelling." The stories depict how food was served, what purpose music served, how classic music had attained a place, slaves:particularly Abyssinian were kept by the rich folk and these slaves were well read to read out poetry, play music and perform other arts.

Meanwhile, Panchatantra makes use of animal characters to convey to us the moral lessons that the author might have considered important to be understood. Interestingly one of the first translations was made in Arabic. A reason for this could be the discriminatory system of caste in the country which would give the stories a different direction. "The stories of the 'Panchatantra' offer us the possibility of making our lives richer and more meaningful. Through the wisdom of its fables the 'Panchatantra' offers a vision of ourselves, warts and all. In so doing, it makes us aware of the fact that solutions lie within ourselves. The use of animals to present this message is particularly significant since animals are not sentimental; in the words of the translator himself, theirs is a view of life which, "piercing the humbug of every false ideal, reveals with incomparable wit the sources of lasting joy".

Stories of Akbar and Birbal speak of the issues the common man was going through, how they considered their King as someone who would solve all problems and how the king's minister with his wisdom always made the king proud. Similarly the 25 tales of VikramBetaal tell us about the famed king's wisdom while the Betaal's stories speak of complicated situations in the society.

Thus, we see, after the fame Arabian nights gained in India and world over, it affectedthe Indian literature and language in different ways. Due to the advent of Arabic language.Islamic education grew and developed in India. Many thinkers,writers, intellectuals were born and brought up in India and influenced the Islamic thought as well as contributed to both indian and Arabic languages. The languages like Arabic and Persian influenced Indian languages and on the other hand indian languages influenced Arabic. panchatantra with it's earliest translation in Arabic gained wide readership in arab speaking countries and impacted the literature there. Fables became more widely read and started forming the major part of children's literature.

Realism has taken over literature; fantasy-and other genres-have been deemed childish garbage.Ursula K. Le GuinIn her article "The Critics, the Monsters and the Fantasists," writes," Universities have taught generations of students to shun genres, including fantasy (unless it was written before 1900, wasn't written in English, and/ or can be labelled magic realism).

Not only does fantasy remind us of what we are, it reminds us of what we once were. The industrialization of our current world has severed us from the connection we used to have with nature.in the same article Le Guin says, "The fields and forests, the villages and byroads, once did belong to us, when we belonged to them. That is the truth of the non-industrial setting of so much fantasy. It reminds us of what we have denied, what we have exiled ourselves from.

Animals were once more to us than meat, pests, or pets: they were fellow-creatures, colleagues, dangerous equals ... what fantasy generally does that the realistic novel generally cannot do is include the nonhuman as essential."

In J.R.R. Tolkein's words “'“Fantasy is escapist, and that is its glory. If a soldier is imprisioned by the enemy, don't we consider it his duty to escape?. . If we value the freedom of mind and soul, if we're partisans of liberty, then it's our plain duty to escape, and to take as many people with us as we can!"

\section{REFERENCES}

[1] Hoh, Anchi. "A Thousand and One Nights: Arabian Storytelling in World Literature" ,October 26, 2017 https://blogs.loc.gov/international-collections/2017/10/athousand-and-one-nights-arabian-story-telling-in-worldliterature/ (Accessed on $26^{\text {th }}$ Feb, 2020)

[2] Angelskår,Svein. "Policing Fantasy:Problems of Genre in Fantasy Literature" https://www.duo.uio.no/bitstream/handle/10852/25415/31942. pdf?sequence $=1$ (Accessed on $26^{\text {th }} \mathrm{Feb}, 2020$ )

[3] Gadre,Mandar. "The 'Panchatantra' and Caste in India" https://medium.com/@amaltaash/the-panchatantra-and-castein-india-369649c5b34e (Accessed on 26th Feb, 2020)

[4] Musawi,Muhsin J. The Islamic Context of The Thousand and One Nights, Columbia University press, (May 2009) 